\title{
Neutrophil-to-lymphocyte ratio as a predictor of acute appendicitis
}

\author{
Şahin Kahramanca, M.D., ${ }^{1 \#}$ Gülay Özgehan, M.D., ${ }^{1}$ Duray Şeker, M.D.,, Emre İsmail Gökce, M.D., ${ }^{1}$ \\ Gaye Şeker, M.D., ${ }^{1}$ Gündüz Tunç, M.D., ${ }^{2}$ Tevfik Küçükpınar, M.D., ${ }^{1}$ Hülagü Kargıcı, M.D. ${ }^{1}$
}

${ }^{1}$ Department of General Surgery, Diskapi Yildirim Beyazit Training and Research Hospital, Ankara;

${ }^{2}$ Department of General Surgery, Acibadem Hospital, Ankara

\begin{abstract}
BACKGROUND: Accurately diagnosing appendicitis can be difficult. This retrospective study aimed to evaluate the ability of the neutrophil-to-lymphocyte ratio (NLR) to predict acute appendicitis pre-operatively and to differentiate between simple and complicated appendicitis.
\end{abstract}

METHODS: A database of 1067 patients who underwent surgery was evaluated. Based on postoperative histopathological examination, the patients were divided into two groups: acute appendicitis (GI) and normal appendix (G2). Patients in the acute appendicitis group were further divided into two subgroups: simple appendicitis ( $\mathrm{Gla}$ ) and complicated (gangrenous and perforated) appendicitis (GIb).

RESULTS: GI included 897 patients and G2 included I 70 patients. Among the $897 \mathrm{GI}$ patients, there were $753 \mathrm{Gla}$ patients and I 44 GIb patients. A NLR of 4.68 was associated with acute appendicitis ( $\mathrm{GI}$ vs $\mathrm{G} 2, \mathrm{p}<0.00 \mathrm{I}$ ). The sensitivity and specificity were $65.3 \%$ and $54.7 \%$, respectively. A NLR of 5.74 was associated with complicated appendicitis ( $\mathrm{Gla} v \mathrm{G} \mathrm{Gl}$, $\mathrm{p}<0.00 \mathrm{I}$ ). The sensitivity and specificity of the two clinical features were $70.8 \%$ and $48.5 \%$, respectively.

CONCLUSION: We suggest that preoperative NLR is a useful parameter to aid in the diagnosis of acute appendicitis and differentiate between simple and complicated appendicitis, and can be used as an adjunct to the clinical examination.

Key words: Appendicitis; complicated appendicitis; lymphocyte; neutrophil.

\section{INTRODUCTION}

Acute appendicitis (AA) is one of the most common causes of acute abdomen. The lifetime occurrence of this disease is approximately $7 \%$, with perforation rates of $17-20 \% .^{[1]}$ The mortality risk is less than $1 \%$ in the general population, but this number can rise to $50 \%$ among the elderly population. $[2,3]$ This entity has some well-known signs and symptoms, like increased leukocyte count and right lower quadrant pain. However, these predictors are not constant and their accu-

\footnotetext{
\#Current affliation: Department of General Surgery, Kars State Hospital, Kars, Turkey

Address for correspondence: Şahin Kahramanca, M.D.

Kars Devlet Hastanesi, Genel Cerrahi Kliniği, Kars, Turkey

Tel: +90 474 - 2125668 E-mail: drkahramancasahin@gmail.com

Qucik Response Code Ulus Travma Acil Cerr Derg

2014:20(I):19-22

doi: $10.5505 /$ tjtes.20I4.20688

Copyright 2014

TJTES
}

racy is questionable. Many authors have reported that a raised leukocyte count is a sensitive test for AA but is not diagnostic because of its low sensitivity. ${ }^{[4,5]}$ Further, atypical presentations are not infrequent, especially in the elderly. To overcome morbidity and mortality of perforation before surgery, a negative appendectomy is somewhat acceptable traditionally. However, in recent years, many have considered this unacceptable, and have studied means of improving the preoperative diagnosis, ${ }^{[6-8]}$ since the operation itself is a cause of morbidity and mortality. In recent years, some authors reported that the neutrophil-to-lymphocyte ratio (NLR) is a predictor of inflammation and useful in the preoperative diagnosis of $A A^{[9-11]}$

In this study, we suggest that calculation of the NLR may provide a sensitive parameter in the preoperative prediction of $\mathrm{AA}$ and may help preoperatively to differentiate complicated from non-complicated appendicitis. We also suggest that this parameter may prevent negative appendectomies based on its predictive value.

\section{MATERIALS AND METHODS}

We retrospectively reviewed a database of I I 84 patients who 
had undergone open appendectomy for a preoperative diagnosis of AA between 2005 and 2013. The clinical diagnosis of AA was established preoperatively by means of clinical history, physical examination, traditional laboratory tests, and in some patients, by imaging studies like ultrasonography. Laboratory tests were performed on blood samples obtained on admission to the hospital. The leukocyte count and neutrophil percentage were measured by an automated hematology analyzer (Coulter ${ }^{\circledR}$ LH 780 Hematology Analyzer, Beckman Coulter Inc., Brea, CA, USA). The upper limits of the reference interval for leukocyte counts were 4500-10300/ $\mu \mathrm{L}$.

One hundred and seventeen patients with a normal appendix, but who had another pathological process diagnosed intraoperatively that explained their presentation of acute abdomen, were excluded. Totally, the data of 1067 patients were analyzed. Pathology reports were used to determine whether the appendix was inflamed or normal. According to pathology reports, patients were grouped into two as positive appendectomy (GI) and negative appendectomy (G2) groups. For subgroup analysis, GI was divided into two as complicated ( $\mathrm{Gla}$ ) and non-complicated (GIb) appendicitis according to the intraoperative findings. Complicated appendicitis was defined as gangrenous and/or perforated appendicitis.

\section{Statistical Analysis}

The data analysis was performed using the Statistical Package for the Social Sciences for Windows, version 17.0 (SPSS Inc, Chicago, IL, USA). Whether the distributions of continuous variables were normal or not was determined by Shapiro-Wilk test. Data were shown as mean \pm standard deviation or median (min-max), where applicable. The differences between groups

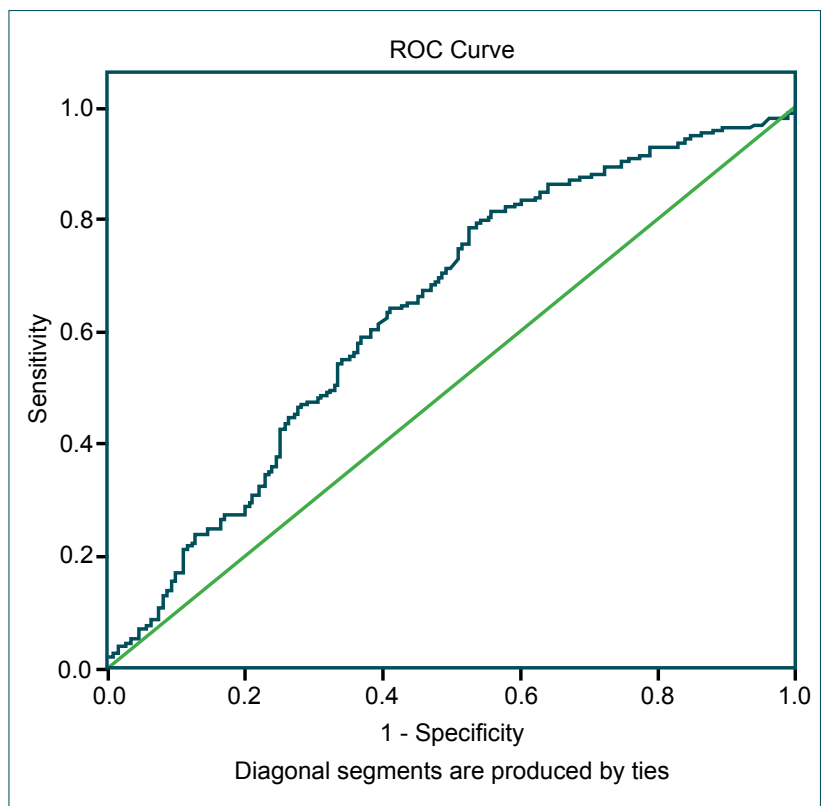

Figure 1. ROC curve for negative and positive appendectomies. The area under ROC curve: $0.639 .95 \% \mathrm{Cl} \quad 0.591-0.687$; $p$ value $<0.001$. were compared by using Student's t or Mann-Whitney U-test, where appropriate. Categorical data were analyzed by Pearson's chi-square test, where appropriate. The cutoff values of parameters for discrimination of the groups were determined using the receiver operating characteristic (ROC) analysis. At each value, the sensitivity and specificity for each outcome under study were plotted, thus generating an ROC curve. A $P$ value less than 0.05 was considered statistically significant.

The recommended cutoff value of the NLR for positive and negative appendectomies was decided using ROC curve analyses. The recommended cutoff value of the NLR was based on the most prominent point on the ROC curve for sensitivity (0.653) and specificity (0.547). Because these two parameters indicated a cutoff value of 4.68 , the recommended NLR cutoff value was defined as 4.68 (Figure I). The area under the ROC curve was 0.639 (95\% confidence interval [Cl] 0.59l-0.687; $\mathrm{p}<0.00 \mathrm{I}$ ). For sub-group analysis, the recommended cutoff value of the NLR was based on the most prominent point on the ROC curve for sensitivity $(0.708)$ and specificity $(0.485)$. Because these two parameters indicated a cutoff value of 5.74 , the recommended NLR cutoff value was defined as 5.74 (Figure 2). The area under the ROC curve was 0.609 (95\% Cl 0.560-0.659; $\mathrm{p}<0.00 \mathrm{I})$.

\section{RESULTS}

The data of 1067 patients were analyzed. The mean age of the analyzed group was $31.22 \pm 11.9$ (SD), and $66.5 \%$ of the patients were male. There were 170 patients in G2, and 897 patients in GI. In subgroups, there were 753 patients in G Ia, and 144 patients in GIb. There was no significant difference in mean age between $G I$ and $G 2(31.0 \pm 11.61$ vs $32.3 \pm 13.28$;

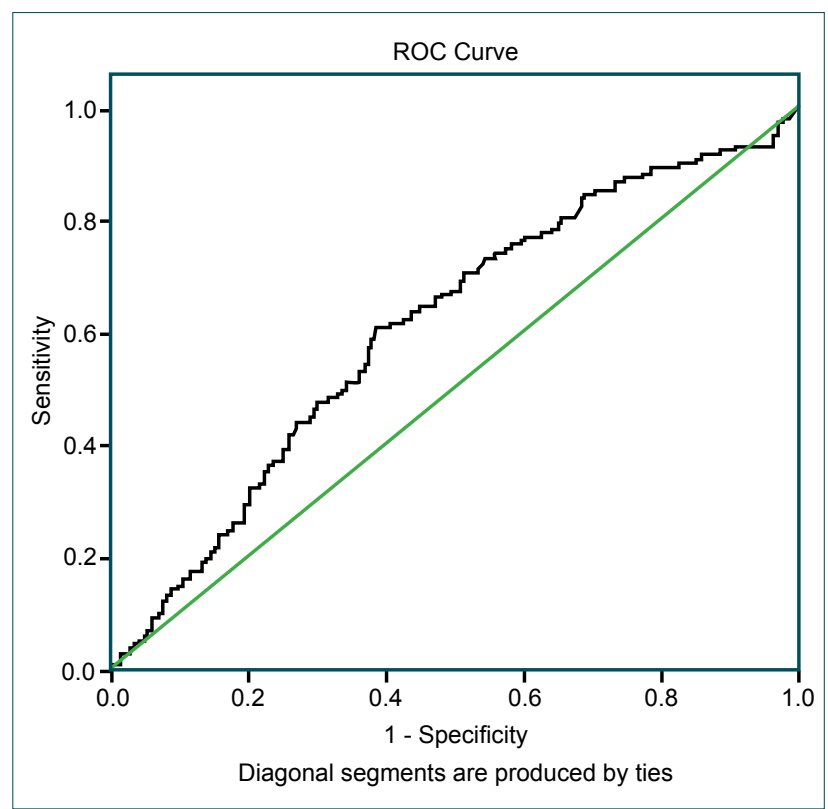

Figure 2. ROC curve for complicated and non-complicated appendectomies. The area under ROC curve: 0.609 . 95\% CI 0.560-0.659; $p$ value $<0.001$ 
Table I. Distribution of patients according to the NLR cutoff values in the main groups

\begin{tabular}{lcc}
\hline Cutoff value of NLR & Negative appendectomy (G2) & Positive appendectomy (GI) \\
\hline$<4.68$ & 93 & 311 \\
$>4.68$ & 77 & 586 \\
Total & 170 & 897 \\
\hline
\end{tabular}

NLR: Neutrophil-to-lymphocyte ratio.

Table 2. Distribution of patients according to the NLR cutoff value in subgroups

\begin{tabular}{lcc}
\hline Cutoff value of NLR & Non-Complicated AA & Complicated AA \\
\hline$<5.74$ & 365 & 42 \\
$>5.74$ & 388 & 102 \\
Total & 753 & 144 \\
\hline AA: Acute appendicitis; NLR: Neutrophil-to-lymphocyte ratio.
\end{tabular}

$\mathrm{p}=0.20 \mathrm{I})$. The male/female ratio was significantly higher in $\mathrm{GI}$ $(69.0 \%$ vs $53.6 \%, p<0.001)$. The mean NLR values in GI and G2 were $8.10 \pm 7.00$ and $5.89 \pm 5.22$, respectively, and there was a significant difference in NLR values between the groups $(p<0.001)$. Cutoff value of NLR was 4.68 , giving a sensitivity of $65.3 \%$ and specificity of $54.7 \%$. Negative predictive value (NPV) was $23.0 \%$ and positive predictive value (PPV) was $88.4 \%$. The mean ages in G $\mathrm{la}$ and G Ib were $36.7 \pm 14.65$ (SD) and $29.9 \pm 10.61(S D)$, respectively, and this difference was significant $(p<0.001)$. There was no significant difference in sex ratio between these subgroups $(p=0.210)$. Mean NLR values for Gla and GIb were $9.85 \pm 8.68$ (SD) and 7.77 \pm 6.59 (SD), respectively. Cutoff value for this subgroup was 5.74 , with a sensitivity of $70.8 \%$ and specificity of $48.5 \%$. PPV was $20.8 \%$ and NPV was $89.7 \%$. Distribution of patients among groups according to the presence or absence of AA and type of appendicitis is given in Tables $I$ and 2 . Intergroup findings are given in Table 3.

\section{DISCUSSION}

Early diagnosis of AA is not always easy. The decision to observe the patient until the diagnosis becomes obvious or to operate early to prevent unwanted complications like perfora- tion and peritonitis represents a serious dilemma for surgeons. An early operation may result in the removal of a normal appendix with a small risk of morbidity. ${ }^{[6-8,12]} \mathrm{AA}$ is most likely an everyday occurrence in emergency units. Especially in rural areas, surgeons may not have imaging facilities. Further, presence of ultrasonography or computed tomography imaging may not help in achieving an accurate diagnosis. Thus, surgeons are still in need of an accurate and easy test to obtain the diagnosis.

Our results show that NLR with a cutoff value of 4.68 can significantly differentiate a normal appendix and inflamed AA. This value is much higher than the numbers given in previous reports, ${ }^{[9,11]}$ but less than the number reported by Ishizuka et al. ${ }^{[13]}$ The sensitivity of this cutoff value is $65.3 \%$, which means that a total of $65 \%$ of patients with histologically confirmed AA have an elevated ratio. The specificity of $54.7 \%$ is also low (thus a high false-positive rate). These low sensitivity and specificity values may be explained by the fact that only operated patients were included in this study; data about other suspected cases who were not operated or were medically treated are unknown. Another interesting finding is that the female to male ratio is significantly higher in the negative appendectomy group. This may be attributed to gynecological diseases mimicking AA.

Table 3. Intergroup comparison

\begin{tabular}{lcccccccc}
\hline Group & Mean NLR & SD (士) & Cutoff value & p & Sensitivity & Specificity & PPV & NPV \\
\hline GI & 8.1 & 7.00 & 4.68 & $<0.001$ & $65.3 \%$ & $54.7 \%$ & $88.4 \%$ & $23 \%$ \\
G2 & 5.89 & 5.22 & & & & & \\
GIa & 9.85 & 8.65 & 5.74 & $<0.001$ & $70.8 \%$ & $48.5 \%$ & $20.8 \%$ & $89.7 \%$ \\
GIb & 7.77 & 6.58 & & & & & \\
\hline
\end{tabular}

GI: Positive appendectomy group; G2: Negative appendectomy group; G la: Complicated appendectomy group; G l b: Non-complicated appendectomy group; NLR: Neutrophil-to-lymphocyte ratio; PPV: Positive predictive value; NPV: Negative predictive value. 
The cutoff value of NLR for complicated appendicitis was 5.74 , with a sensitivity of $70.8 \%$ and specificity of $48.5 \%$. With regard to sensitivity and specificity values, it seems NLR is more helpful in differentiating complicated cases. Our cutoff value is lower than the value (8.00) recommended for the differentiation of gangrenous appendicitis in the report of Ishizuka et al. ${ }^{[13]}$ In the study of Yazici et al., ${ }^{\left[{ }^{11]}\right]}$ it was reported that the sensitivity is maximum when NLR is $>3.5$, but specificity and PPV increase steadily when NLR increases, and the most prominent values are reached when NLR is $>5.0$. There are very few studies on this subject, but all reported that NLR appears to have greater diagnostic accuracy than traditional diagnostic laboratory tests (either white blood cell or C-reactive protein alone). It is also reported that NLR on admission to the hospital is an independent predictor of positive appendicitis histology. ${ }^{[10]}$ Further, lymphocyte counts may even fall in appendicitis, with the largest decrease occurring in gangrenous appendicitis. ${ }^{[7,14-17]}$ This phenomenon may explain the higher cutoff value in complicated appendicitis. The significant rise in NLR in cases without complicated appendicitis may be explained by a greater increase in the number of neutrophils in comparison with leukocyte count in the beginning of the acute phase of acute inflammation.

In conclusion, according to the results of our study, NLR of 4.68 seems to be a reliable parameter to obtain a more certain diagnosis of acute appendicitis, and NLR of 5.74 may help to differentiate complicated from non-complicated appendicitis. However, a normal value for NLR does not exclude the diagnosis. To find the optimal NLR and to test its accuracy, prospective randomized studies are needed. The clinical evaluation by the surgeon should continue to take precedence.

Conflict of interest: None declared.

\section{REFERENCES}

1. Storm-Dickerson TL, Horattas MC. What have we learned over the past 20 years about appendicitis in the elderly? Am J Surg 2003;185:198-201.
2. Franz MG, Norman J, Fabri PJ. Increased morbidity of appendicitis with advancing age. Am Surg 1995;61:40-4.

3. Freund HR, Rubinstein E. Appendicitis in the aged. Is it really different? Am Surg 1984;50:573-6.

4. Yang HR, Wang YC, Chung PK, Chen WK, Jeng LB, Chen RJ. Role of leukocyte count, neutrophil percentage, and C-reactive protein in the diagnosis of acute appendicitis in the elderly. Am Surg 2005;71:344-7.

5. Hallan S, Asberg A, Edna TH. Additional value of biochemical tests in suspected acute appendicitis. Eur J Surg 1997;163:533-8.

6. Schellekens DH, Hulsewé KW, van Acker BA, van Bijnen AA, de Jaegere TM, Sastrowijoto SH, et al. Evaluation of the diagnostic accuracy of plasma markers for early diagnosis in patients suspected for acute appendicitis. Acad Emerg Med 2013;20:703-10. CrossRef

7. Hoffmann J, Rasmussen OO. Aids in the diagnosis of acute appendicitis. Br J Surg 1989;76:774-9. CrossRef

8. Dunn EL, Moore EE, Elerding SC, Murphy JR. The unnecessary laparotomy for appendicitis-can it be decreased? Am Surg 1982;48:320-3.

9. Goodman DA, Goodman CB, MonkJS. Use of the neutrophil:lymphocyte ratio in the diagnosis of appendicitis. Am Surg 1995;61:257-9.

10. Markar SR, Karthikesalingam A, Falzon A, Kan Y. The diagnostic value of neutrophil: lymphocyte ratio in adults with suspected acute appendicitis. Acta Chir Belg 2010;110:543-7.

11. Yazici M, Ozkisacik S, Oztan MO, Gürsoy H. Neutrophil/lymphocyte ratio in the diagnosis of childhood appendicitis. Turk J Pediatr 2010;52:400-3.

12. Mason RJ, Moazzez A, Sohn H, Katkhouda N. Meta-analysis of randomized trials comparing antibiotic therapy with appendectomy for acute uncomplicated (no abscess or phlegmon) appendicitis. Surg Infect (Larchmt) 2012;13:74-84. CrossRef

13. Ishizuka M, Shimizu T, Kubota K. Neutrophil-to-Lymphocyte Ratio Has a Close Association With Gangrenous Appendicitis in Patients Undergoing Appendectomy. Int Surg 2012;97:299-304. CrossRef

14. Raftery AT. The value of the leucocyte count in the diagnosis of acute appendicitis. Br J Surg 1976;63:143-4. CrossRef

15. Doraiswamy NV. Leucocyte counts in the diagnosis and prognosis of acute appendicitis in children. Br J Surg 1979;66:782-4. CrossRef

16. English DC, Allen W, Coppola ED, Sher A. Excessive dependence on the leukocytosis cue in diagnosing appendicitis. Am Surg 1977;43:399-402.

17. Sasso RD, Hanna EA, Moore DL. Leukocytic and neutrophilic counts in acute appendicitis. Am J Surg 1970;120:563-6. CrossRef

\title{
KLINIK ÇALIŞMA - ÖZET
}

\section{Nötrofil/lenfosit oranının akut apandisit tanısındaki belirleyiciliği}

\author{
Dr. Şahin Kahramanca, ${ }^{1 \# ~ D r . ~ G u ̈ l a y ~ O ̈ z g e h a n, ~}{ }^{1}$ Dr. Duray Şeker, ${ }^{1}$ Dr. Emre İsmail Gökce, ${ }^{1}$ \\ Dr. Gaye Şeker, ${ }^{1}$ Dr. Gündüz Tunç, ${ }^{2}$ Dr. Tevfik Küçükpınar, ${ }^{1}$ Dr. Hülagü Kargıcı ${ }^{1}$ \\ ${ }^{1}$ Dışkapı Yııdırım Beyazıt Eğitim ve Araştırma Hastanesi, Genel Cerrahi Kliniği, Ankara; \\ ${ }^{2}$ Acıbadem Hastanesi, Genel Cerrahi Kliniği, Ankara
}

AMAÇ: Akut apandisitin tanısı zor olabilmektedir. Bu retrospektif çalışmada, nötrofil/lenfosit oranının (NLR) akut apandisit tanısındaki ve komplike apandisit ile basit apandisit ayrımındaki belirleyiciliği araştııılı.

GEREÇ VE YÖNTEM: Akut apandisit tanısı ile ameliyat edilmiş 1067 hastanın kayıtları retrospektif olarak incelendi. Histopatolojik değerlendirmeye göre hastalar akut apandisit (GI) ve normal appendiks (G2) olarak iki ana gruba ayrıldı. Akut apandisit grubundaki hastalar ise yeniden basit apandisit ve komplike (perfore ve gangrene) olarak alt iki gruba ayrıldı.

BULGULAR: GI grubunda 897, G2 grubunda 170 hasta vardı. Gla'da 753, GIb'de ise I 44 hasta vardı. Akut apandisit tanısı konulmasında NLR için cut-off değeri $4.68(p<0.00$ I) olarak hesaplandı. Sensitivite \%65.3, spesifite ise \%54.7 idi. Komplike apandisit ayırımı için NLR cut-off değeri 5.74 olarak hesaplandı. Sensitivitesi \%70.8, spesifitesi ise \%48.5 idi.

TARTIŞMA: Akut apandisit tanısının konulmasında ve komplike apandisit ayrımında NLR klinik değerlendirmeye ek olarak faydalı bir parametredir. Anahtar sözcükler: Apandisit; komplike apandisit; lenfosit; nötrofil.

\#Şimdiki kurumu: Kars Devlet Hastanesi, Genel Cerrahi Kliniği, Kars

Ulus Travma Acil Cerr Derg 20 I4;20(I):19-22 doi: I0.5505/tjtes.20।4.20688 